University of Nebraska - Lincoln

DigitalCommons@University of Nebraska - Lincoln

$5-2002$

Ecogeographic surveys as tools for analyzing potential reproductive isolating mechanisms: An example using Solanum juglandifolium Dunal, S. ochranthum Dunal, S. lycopersicoides Dunal, and S. sitiens I. M. Johnston

Stacey DeWitt Smith

University of Nebraska - Lincoln, ssmith19@unl.edu

Iris Edith Peralta

National University of Cuyo, Argentina, iperalta@lab.cricyt.edu.ar

Follow this and additional works at: https://digitalcommons.unl.edu/bioscifacpub

Part of the Life Sciences Commons

Smith, Stacey DeWitt and Peralta, Iris Edith, "Ecogeographic surveys as tools for analyzing potential reproductive isolating mechanisms: An example using Solanum juglandifolium Dunal, S. ochranthum Dunal, S. lycopersicoides Dunal, and S. sitiens I. M. Johnston" (2002). Faculty Publications in the Biological Sciences. 134.

https://digitalcommons.unl.edu/bioscifacpub/134

This Article is brought to you for free and open access by the Papers in the Biological Sciences at DigitalCommons@University of Nebraska - Lincoln. It has been accepted for inclusion in Faculty Publications in the Biological Sciences by an authorized administrator of DigitalCommons@University of Nebraska - Lincoln. 


\title{
Ecogeographic surveys as tools for analyzing potential reproductive isolating mechanisms: an example using Solanum juglandifolium Dunal, S. ochran- thum Dunal, S. lycopersicoides Dunal, and $S$. sitiens I. M. Johnston
}

\author{
Stacey D. Smith ${ }^{1} \&$ Iris Edith Peralta ${ }^{2}$ \\ ${ }^{1}$ School of Biosciences, University of Birmingham, Edgbaston, Birmingham, B15 2TT, U.K. Current Address: \\ Department of Botany, 132 Birge Hall, 430 Lincoln Drive, University of Wisconsin, Madison, Wisconsin \\ 53706, U.S.A. E-mail: sdsmith4@students.wisc.edu (author for correspondence) \\ ${ }^{2}$ Department of Biological Sciences, National University of Cuyo, Alte. Brown 500, 5507 Chacras de Coria, \\ Mendoza, Argentina. E-mail: iperalta@lab.cricyt.edu.ar
}

\begin{abstract}
An ecogeographic survey was completed for two pairs of South American Solanum species: (1) S. juglandifolium and S. ochranthum, and (2) S. lycopersicoides and S. sitiens. The purpose of this survey was to characterize the distribution, ecology, and phenology of these species and to screen for factors that might constitute premating reproductive isolating mechanisms between each pair. Passport data from 276 herbarium specimens were entered into a database, which was subsequently analyzed to determine the ecogeographic distribution and phenology of the surveyed species. The differences between species uncovered by the survey were then considered in the context of reproductive isolation. As $S$. juglandifolium and S. ochranthum were found to have overlapping ecogeographic preferences and phenology, it was postulated that postmating isolating mechanisms form the principal barrier to hybridization between the two species. Unlike S. juglandifolium and S. ochranthum, S. lycopersicoides and S. sitiens differed markedly in ecogeographic distribution. The species have been successfully crossed several times artificially, so the differences in distribution found in this survey probably contribute to maintaining species barriers between the two. In summary, this ecogeographic survey provided a useful method for analyzing the potential for interspecific gene flow between closely related taxa.
\end{abstract}

KEYWORDS: ecogeographic survey, reproductive isolating mechanisms, Solanaceae, Solanum, South America, speciation.

\section{INTRODUCTION}

Species barriers between congeners are maintained by a number of isolating mechanisms, which fall into two broad categories: premating and postmating (Levin, 1978). Premating reproductive isolating mechanisms include spatial, temporal, and floral factors that prevent the transfer of gametes from one species to the next. Postmating factors, such as cross-incompatibility and hybrid inviability, are those that prevent either fertilization or the subsequent formation of fertile hybrid offspring.

This study used an ecogeographic survey to examine several potential premating isolating mechanisms for four species of Solanum. An ecogeographic survey involves the gathering and synthesis of ecological, geographical and taxonomic information, often obtained from passport data (location of collection, collection date, etc.) on herbarium specimen labels (Maxted \& al., 1995; Guarino \& al., 1999). Ecogeographic surveys are most frequently used as predictive tools for planning the collection of plant genetic resources and formulating conservation priorities. A synthesis of ecological and geographical data for a group of taxa can also be used to screen certain potential isolating mechanisms, e.g., spatial and temporal factors.

The ecogeographic survey presented here focused on two pairs of sister taxa: (1) Solanum juglandifolium Dun. and S. ochranthum Dun., and (2) S. lycopersicoides Dun. and $S$. sitiens Johnston. All four species occur exclusively in South America and are members of the subgenus Potatoe (G. Don) D'Arcy. These taxa possess interesting morphological traits apparently intermediate to potato and tomato. Like the potatoes, they exhibit free anthers without interlocking marginal hairs, although they are all yellow-flowered and without tubers like the tomatoes. Traditionally, they have been placed with the potatoes because they lack the sterile anther appendages characteristic of the tomatoes. Nevertheless, Shaw (1998) included these four species within tomatoes and made new combinations for them under Lycopersicon. 


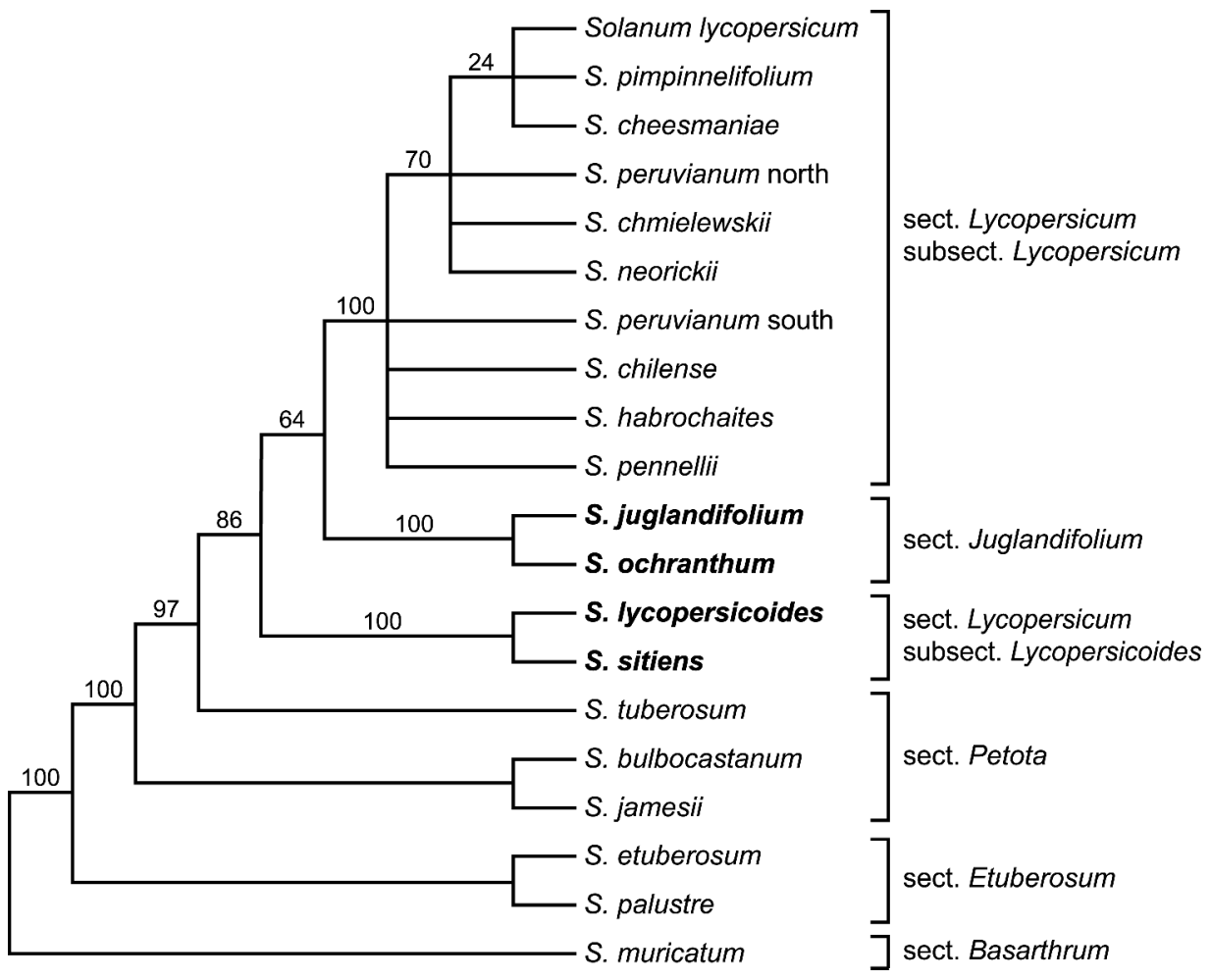

Fig. 1. Phylogenetic relationships among study species (bold letters) and closely related taxa in Solanum subgenus Potatoe (adapted from the GBSSI "waxy" gene sequence phylogeny of Peralta \& Spooner, 2001). Bootstrap values are shown above branches.

The taxonomic position of $S$. juglandifolium, $S$. ochranthum, $S$. lycopersicoides and $S$. sitiens and indeed of the tomatoes themselves has long been the subject of controversy (Peralta \& Spooner, 2000). Solanum lycopersicoides and $S$. sitiens, once grouped together with $S$. juglandifolium and $S$. ochranthum in subsection Juglandifolia (Rydb.) Hawkes, have now been removed to form subsection Lycopersicoides Child within section Lycopersicum (Mill.) Wettst. (Child, 1990; Table 1). Recent phylogenetic analysis using chloroplast DNA (cpDNA) restriction site data revealed that section Juglandifolium Child and subsection Lycopersicoides Child constitute two separate monophyletic groups, sister to the tomatoes (Spooner \& al., 1993; Peralta \&

Table 1. Classification of Solanum subgenus Potatoe by Child (1990). Only the eight sections in the "Tuberarium" relationship are shown. The species used in this study are listed below their section or subsection.

\begin{tabular}{lcc}
\hline Section & Subsection & Species \\
\hline Petota Dumort [incl. potatoes] & & \\
Etuberosum (Buk. \& Kameraz) Child & & S. juglandifolium Dun. \\
Basarthrum Bitter & & S. ochranthum Dun. \\
Juglandifolium (Rydb.) Child & & \\
Articulatum (Rydb.) Child & & \\
Anarrhichomenum Bitter & & Sycopersicum \\
Lycopersicum (Mill.) Wettst. & {$[$ lincludes tomatoes] } & S. sitiens Johnston \\
\end{tabular}


Spooner, 2001; Fig. 1). Consistent with morphological data, the entire clade comprised of sections Lycopersicum and Juglandifolium was nested within subgenus Potatoe (Fig. 1). Thus, among the taxa comprising subgenus Potatoe, section Juglandifolium and subsection Lycopersicoides are supported as the most closely related and probably ancestral to the tomatoes, subsection Lycopersicum (Child, 1990; Spooner \& al., 1993; Peralta \& Spooner, 2001).

The objective of this study was to use an ecogeographic survey to examine potential spatial isolating mechanisms, i.e., differences in ecogeographic preferences, as well as temporal isolating mechanisms, e.g., phenological differences, for each pair of species. A database was created to store information from herbarium specimens gathered as part of the ecogeographic survey. Ecogeographic and phenological differences were then analyzed by querying the database, and findings were considered in the context of other possible species isolating mechanisms.

\section{MATERIALS AND METHODS}

Data source. - Passport data were collected from 276 specimens at the herbarium of the Natural History Museum, London (BM) that were on loan from 21 major herbaria world-wide for an ongoing revision of the tomatoes. Dr. Sandra Knapp (BM) identified all specimens prior to the start of the survey. In total, Solanum juglandifolium was represented by 167 specimens, S. ochranthum 73, S. lycopersicoides 19 and S. sitiens 17 . Clearly, the more herbarium specimens available and herbaria sampled, the more valuable and predictive are the survey results. In this case, a large number of herbaria were sampled, but the numbers of specimens were low for $S$. lycopersicoides and $S$. sitiens.

Duplicates of herbarium specimens (50 in total) were included in the survey for the following reasons. First, the labels of the duplicates often contained different passport data, which could constitute novel ecogeographic information. Second, duplicates were occasionally taken from different parts of the plant such that one specimen might have young fruit and the other just flowers, providing important phenological data. Third, documentation of the number and sources of duplicates was important for future users of the database doing revisionary work.

Database construction. - The information gathered from the specimens was divided into 33 fields (e.g., country of collection, collector's name, date, etc.) and entered into a Microsoft Access $\bigodot$ database. In order to minimize errors in repeated entries, several fields were coded using Taxonomic Database Working Group

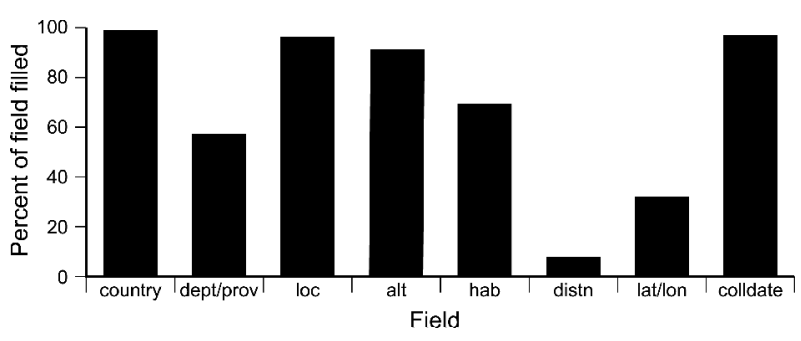

Fig. 2. Percentage of selected fields filled using passport data. Eight fields are shown: country, dept/prov (department or province), loc (location), alt (altitude), hab (habitat), distn (distribution), lat/lon (latitude and longitude), and colldate (collection date). Note: values for latitude and longitude were found for all but 15 of the 276 specimens using Encarta World Atlas.

(TDWG) standard codes for countries and herbaria, provided by Hollis \& Brummitt (1992) and Holmgren \& al. (1990), respectively. When not included on the specimen label, the latitude and longitude values were found using Microsoft Encarta World Atlas $@$ 1998. Figure 2 summarizes the amount of information available from the specimens.

Geographical distribution. - The geographic preferences of each taxon were determined by analyzing the database. The Microsoft Access $\odot$ query function was used to request and retrieve the latitude and longitude for each specimen. These values were then exported to ArcView 3.1 to produce dot distribution maps.

Ecology. - Ecological preferences were difficult to analyze due to the great variation in information provided on the labels. While some labels contained little or no habitat information, others provided detailed descriptions of the site, surrounding vegetation, soil, amount of rainfall, etc. To allow for comparison of ecological preferences between species, relevant data were grouped into four principal categories: level of disturbance, vegetation type, microhabitat, and substrate (soil).

The altitudinal range for each taxon was determined by identifying specimens at the minimum and maximum altitudes. The ranges were divided into 100 meter classes, and the number of specimens in each class was calculated. These data were plotted in the form of a bar graph for easy comparison. Percentages of specimens in each class were used instead of absolute numbers to compensate for the differences in numbers of specimens between the species.

Phenology. - The flowering phenology of each species was estimated by recording the presence or absence of flowers on specimens. The number of flowering specimens of each species in a given month was retrieved using queries. The small number of specimens available for $S$. lycopersicoides and $S$. sitiens limited the 

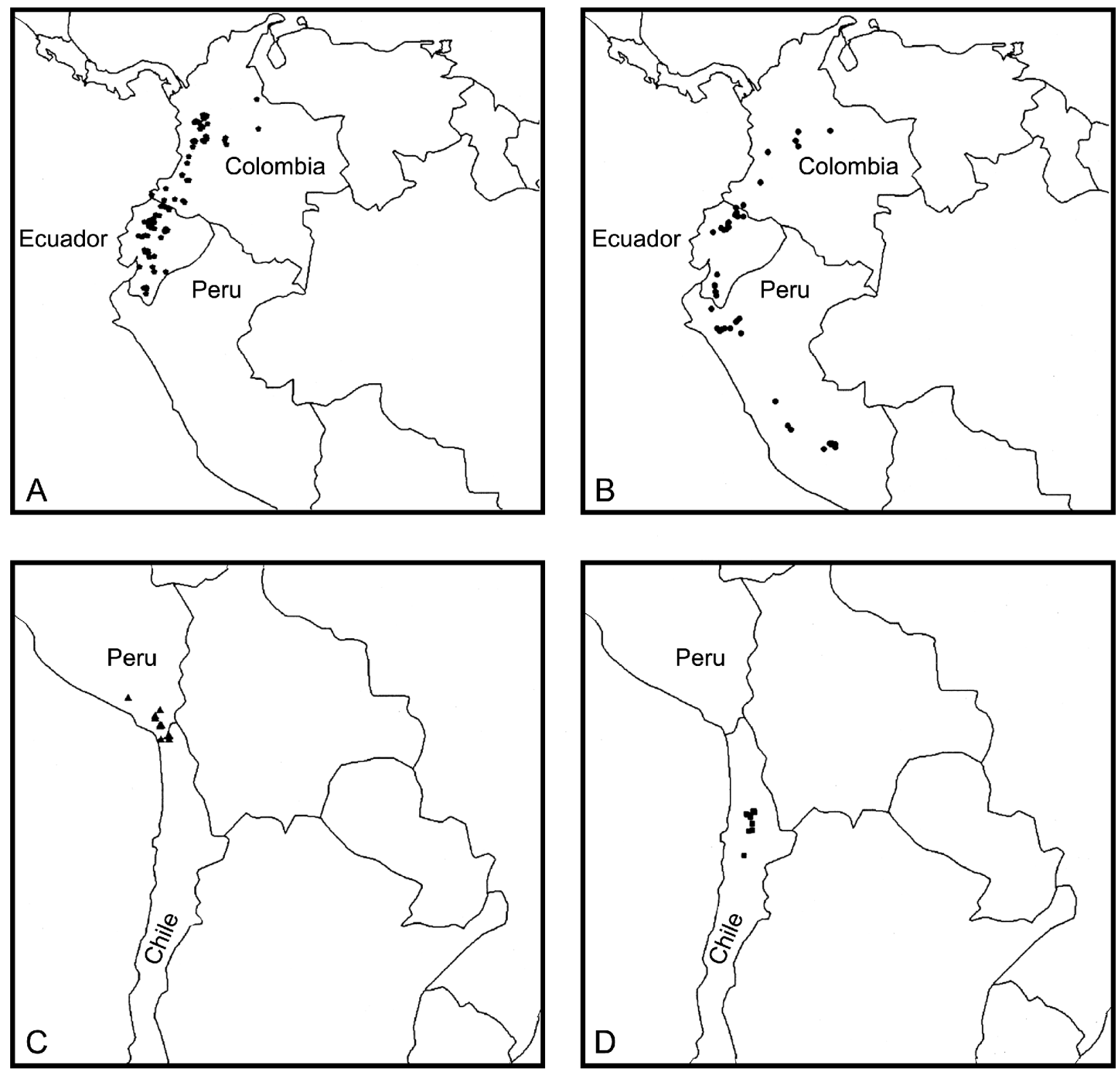

Fig. 3. Geographical distribution of species of Solanaceae in South America. A, S. juglandifolium; B, S. ochranthum; C, S. lycopersicoides; D, S. sitiens.

accuracy of the phenological patterns identified and discussed below.

\section{RESULTS}

Geographical distribution. - Solanum juglandifolium and $S$. ochranthum are extensively sympatric. The two species are found along both sides of the Andes in the northern part of South America. Solanum juglandifolium exhibits a continuous distribution, occurring along the eastern side of Ecuador and Colombia (Fig. 3A). In Colombia, this species is distributed along the three principal mountain ranges: the Cordillera Occidental, which runs up the coast, the Cordillera Central, and the Cordillera Oriental, which continues north toward Venezuela. With a slightly more elongated and disjunct distribution, S. ochranthum is found in Peru, Ecuador and Colombia (Fig. 3B). No major environmental differences seem to account for the gaps in its distribution, so perhaps the species was simply poorly collected in central Ecuador and central Peru. Hawkes (1990) 


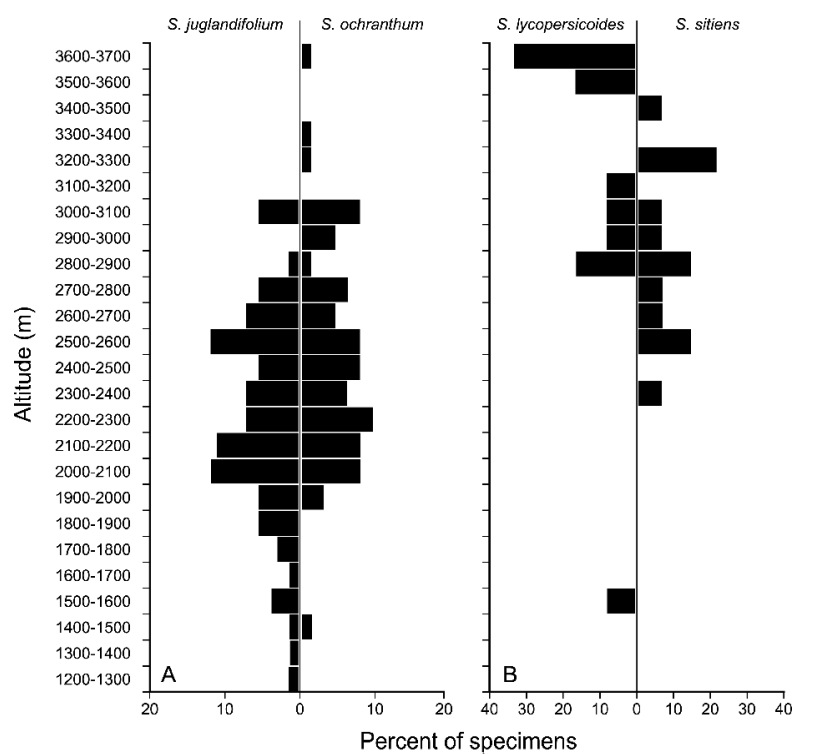

Fig. 4. Percentages of specimens from different altitudes. A, S. juglandifolium and S. ochranthum; B, S. lycopersicoides and $S$. sitiens.

listed S. juglandifolium as also occurring in Costa Rica and Venezuela, although this appears to be based on a single specimen collected in the 1840's from Central America (with no other locality data) and a specimen from Venezuela with neither date nor locality data (Hawkes, 1997, and the database cited therein). Neither specimen was seen during this survey. The lack of other specimens of $S$. juglandifolium from Central America or Venezuela suggests that these two specimens may have been mislabeled or misidentified.

Solanum lycopersicoides and $S$. sitiens are allopatric (Fig. 3). This finding agreed with Rick (1988) and descriptions found in the various Floras. Solanum lycopersicoides is found in high elevation areas along the border between Peru and Chile. The range of $S$. lycopersicoides is separated from $S$. sitiens by $150 \mathrm{~km}$ spanning the northern half of the Atacama desert. Solanum sitiens, a narrow endemic, has been collected only from Antofagasta province on the western side of the Andes in northern Chile. The small gaps in distribution of each species (Fig. 3C, D) may be related to the low number of specimens and the difficulty of collecting in these areas as opposed to truly disjunct distributions.

Ecology. - Solanum juglandifolium and S. ochranthum display very similar habitat preferences. They have been collected from a wide range of vegetation types, ranging from primary cloud forest to road verges. However, only $S$. juglandifolium was recorded as occurring in páramo. As Rick (1988) pointed out, both species share a preference for wet areas and are particularly common in riparian sites. The only difference in ecological preferences between the two seems to be the altitude at which they occur. Collections of S. juglandifolium have been made between 1200 and $3048 \mathrm{~m}$, and the average altitude for all specimens is $2201 \mathrm{~m}$. The altitudinal range of specimens of $S$. ochranthum, 1400-3658 m, overlaps with that of $S$. juglandifolium, although the average altitude for $S$. ochranthum $(2474 \mathrm{~m})$ is somewhat higher (Fig. 4A). Previous descriptions of the species (Correll, 1962; Hawkes, 1990) support this preference for slightly higher altitudes. Also, Rick (1988) reported that the two grow at different altitudes and suggested that this difference relates to different temperature preferences and leads to their different, though overlapping, geographical distributions.

Solanum lycopersicoides and S. sitiens also show some overlap in habitat preferences. Unlike the mesic species mentioned above, both occur most often exclusively in arid situations, primarily in dry open areas along roads and trails, but also beside streams and dry riverbeds. Analysis of the database suggested that $S$. lycopersicoides generally occurs at higher altitudes than S. sitiens (Fig. 4B). The range in altitude for S. lycopersicoides is (1500-) 2800 to $3600 \mathrm{~m}$ while the range for $S$. sitiens is $2500-3400 \mathrm{~m}$. The average altitude for S. lycopersicoides was $3082 \mathrm{~m}$ compared to $2878 \mathrm{~m}$ for $S$. sitiens. The average for $S$. lycopersicoides increases to $3226 \mathrm{~m}$ if the single outlier specimen from $1500 \mathrm{~m}$ is excluded. These values are slightly different than those given by Correll (1962) and Hawkes (1990) who both listed S. lycopersicoides as occurring between 2800 and $3150 \mathrm{~m}$ and $S$. sitiens at $3000 \mathrm{~m}$.

Phenology. - Solanum juglandifolium and $S$.

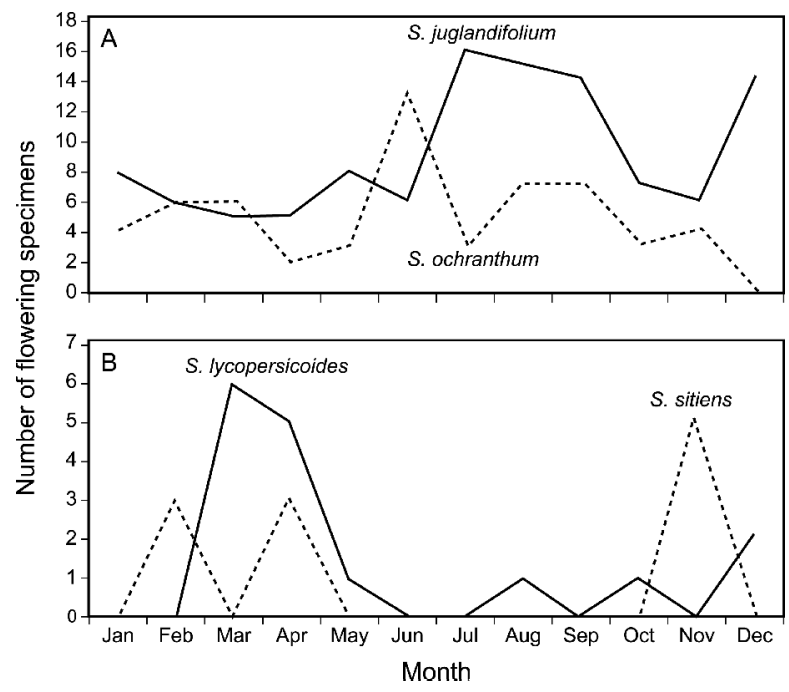

Fig. 5. Number of flowering specimens collected throughout the year. A, S. juglandifolium vs. S. ochranthum; B, S. lycopersicoides vs. S. sitiens. 


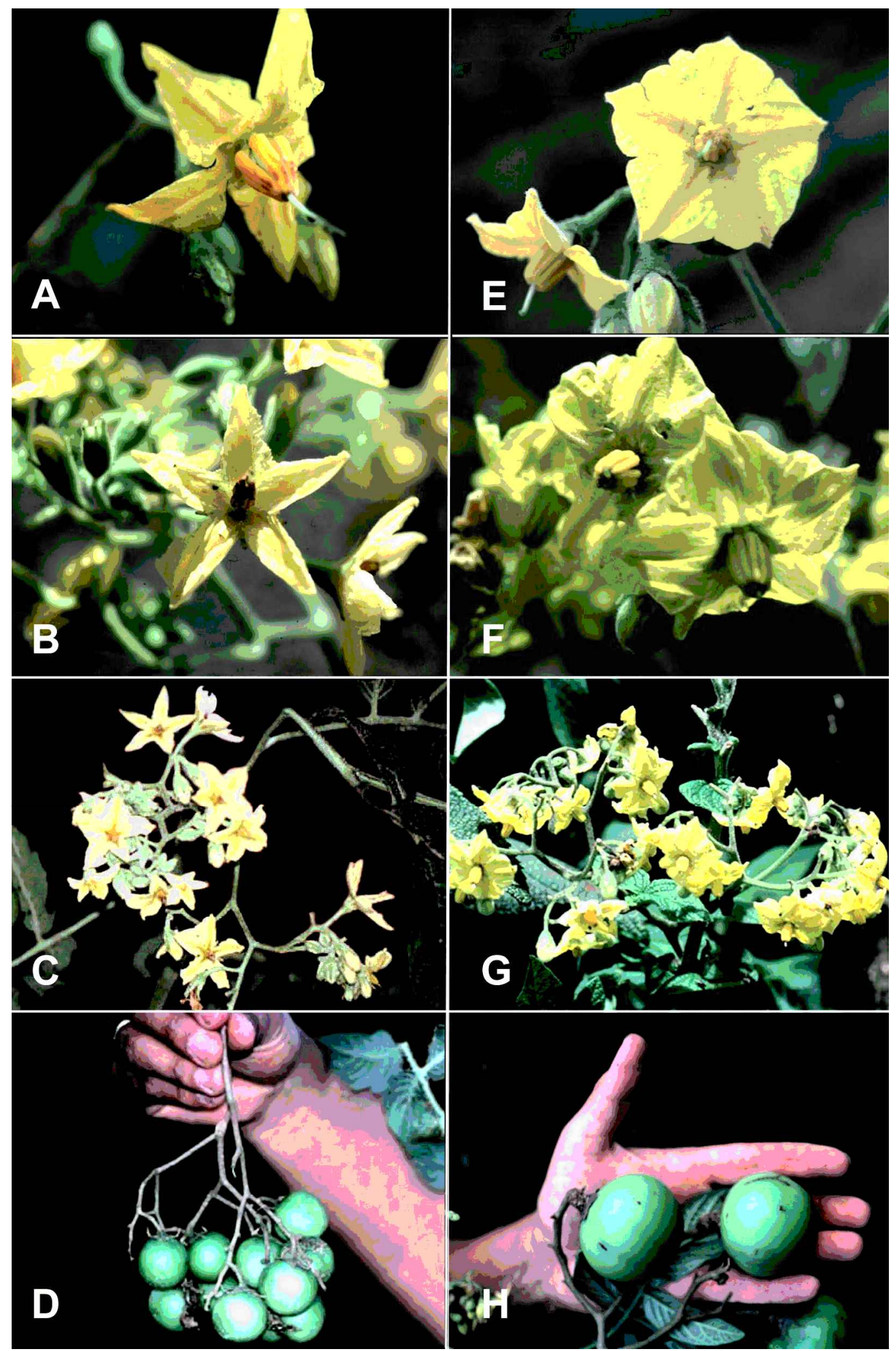

Fig. 6. Solanum juglandifolium. A, B, flower. C, inflorescence. D, fruits. Solanum ochranthum. E, F, flower. G, inflorescence. $\mathrm{H}$, fruits. Photos by David M. Spooner. 
ochranthum have very similar flowering phenology. In agreement with Correll (1962), the survey showed that both flower sporadically throughout the year (Fig. 5A). The highest number of flowering specimens was collected in July for $S$. juglandifolium and in June for S. ochranthum, a pattern which may reflect a stimulus to flower at the beginning of the wet season. Solanum juglandifolium flowered all year throughout its range. Solanum ochranthum appears to flower mostly from January to March and from May to November in Peru and Ecuador and sporadically from April to October in Colombia. Where $S$. juglandifolium and $S$. ochranthum co-occur in Ecuador and Colombia, there would be a good chance that their flowering times overlap. For example, both species occurred in the city of Maldonado in the Carchi Province of Ecuador, and flowering specimens of both have been collected in May. Thus, it appears that there is no phenological separation between the species.

Greater differences are noted in the flowering times of $S$. lycopersicoides and S. sitiens (Fig. 5B). The few specimens available suggest that $S$. lycopersicoides flowers principally in March and April and occasionally in August, October, and December. Correll (1962) stated that this species flowers from December to April; however, our survey indicates that the flowering period is, in fact, more sporadic. Flowering specimens of $S$. sitiens have only been collected in the months of February, April, and November, which contrasts to Correll's (1962) assertion that the species flowers only in January. The greatest potential overlap in the flowering periods of $S$. lycopersicoides and S. sitiens appears to be in April. However, no specimens from similar locations were available to compare flowering times of sympatric populations.

\section{DISCUSSION}

\section{Solanum juglandifolium and S. ochranthum.}

- The premating isolating factors examined here do not appear to be sufficient to keep the two species reproductively isolated, for they are very similar in distribution, ecology and phenology. Only a slight difference in the mean altitudinal range was observed, which did not appear to confer spatial isolation. For instance, specimens of both species have been collected at exactly the same coordinates near the town of Tandapi in Pichincha, Ecuador. In addition, there were many other specimens of the two species collected within a few kilometers of the other. Therefore, spatial isolation alone does not seem to be sufficient to prevent gene flow between the species.

Ethological differences between S. juglandifolium and $S$. ochranthum, not assessed as part of this survey, could serve as an isolating mechanism. Pollen flow between sympatric taxa may be prevented if the taxa utilize different pollinators (Levin, 1978). Solanum juglandifolium and S. ochranthum are buzz-pollinated, the principal mode of pollination in Solanum (Michener, 1962). Insects extracting pollen from the poricidal anthers of these species may maximize the amount of reward obtained for energy expended by specializing for a particular species. This behavior, termed constancy, allows pollinators to forage selectively, focusing on a particular search image (Grant, 1950). The yellow flowers of $S$. juglandifolium are generally larger than those of $S$. ochranthum; this difference may allow pollinators to distinguish between two species and could permit ethological isolation.

Another potential isolating mechanism not explored in this survey is diurnal differences in flowering time. Levin (1978) discussed several cases in which flowers of closely related species stagger their time of anthesis during the day or night. Presumably, this staggering prevents competition for pollinators and improper gene transfer, while serving to reproductively isolate the species. This possibility would seem unlikely for $S$. juglandifolium and S. ochranthum. As noted, both species are buzz-pollinated by bees, which are most active during the daytime hours. This constrains the extent to which the two species could separate the time of flower presentation.

Postmating mechanisms, however, appear to be more plausible isolating factors for $S$. juglandifolium and S. ochranthum. While the small differences in distribution, phenology and floral morphology seem unlikely to foster spatial, temporal or ethological isolation, postmating mechanisms offer greater potential. Prezygotic factors such as pollen-pistil incompatibility or postzygotic factors, such as hybrid inviability, would prevent interspecific gene flow and hybrid formation. Indeed, repeated attempts to cross $S$. juglandifolium and $S$. ochranthum have been unsuccessful (Rick, 1979); cross-pollination resulted in fruit set but inviable seed. Recently, this barrier was overcome by rescuing and culturing the embryos in vitro (R. Chetelat, pers. comm.). The difficulty of hybridizing S. juglandifolium and S. ochranthum suggests that cross-incompatibility constitutes an important barrier to gene flow in nature.

Solanum lycopersicoides and S. sitiens. Unlike S. juglandifolium and S. ochranthum, S. lycopersicoides and $S$. sitiens have extremely restricted and allopatric distributions, which probably serve to isolate them. The differences in their distributions may relate to their different altitudinal ranges. Solanum lycopersicoides apparently tolerates higher altitudes and colder temperatures than $S$. sitiens, but these conclusions are based on less than 20 specimens for each species. Greater numbers of specimens would allow more exact quantification of these differences. 
Their separate distributions may also relate to subtle differences in their ecology, which were not evident from our database. For example, Rick (1988) stated that $S$. sitiens has a higher tolerance than $S$. lycopersicoides for growing in areas of low rainfall. It is mainly found in the Antofagasta region of Chile, which has one of the world's lowest recorded precipitations, less than $0.1 \mathrm{~mm}$ annually (Grosvenor, 1966). Rick found S. sitiens thriving and fruiting in areas so dry that most other species were stunted or perishing. Although often found in arid places, S. lycopersicoides usually grows in more mesic areas and is characterized by its ability to withstand extremely low temperatures (Rick, 1988). These differences may be significant enough to account for spatial isolation of these two species.

The importance of geographical isolation as a barrier to hybrid formation is highlighted by the ease of hybridization between the two species outside of their natural habitat. Rick $(1951,1979)$ reported that artificial crosses of S. lycopersicoides and S. sitiens resulted in the production of viable fertile hybrids. This suggests that if the ranges of the two species overlapped in the wild, hybrid populations would form. Thus, differences in geographical distribution appear to be the most significant isolating mechanism between these two species.

\section{Applications and future directions. -} Completing an ecogeographic survey for S. juglandifolium, S. ochranthum, S. lycopersicoides and S. sitiens provided an opportunity to examine potential premating species isolating mechanisms, namely differences in ecology, geographical distribution and phenology. Analysis of the database compiled during the survey revealed: (1) S. juglandifolium and S. ochranthum exhibit only slight differences in ecology, distribution and phenology, making cross-incompatibility a more likely barrier separating the species in nature; (2) geographical isolation appears to be the most significant factor in separating $S$. lycopersicoides from $S$. sitiens. Further research in the reproductive biology of these species should thus be directed towards these probable isolating mechanisms. For instance, it would be interesting to investigate the genetic factors preventing crossing between the sympatric S. juglandifolium and S. ochranthum; such research would almost certainly have implications for the breeding of potatoes and tomatoes. Also, S. lycopersicoides and $S$. sitiens clearly merit more research to delimit accurately their distributions and to understand better how they cope with such extreme environments. As Rick (1988) suggests, their ability to withstand dry and cold conditions would be very economically important if it could be incorporated into tomatoes and potatoes.

Overall, this work demonstrates the usefulness of ecogeographic surveys in investigating spatial and tem- poral premating isolating mechanisms. As noted earlier, the value of the results obtained from an ecogeographic survey is constrained by the quantity and quality of available specimens. In this case, the large number of specimens for S. juglandifolium and S. ochranthum allowed for more precise characterization of their geography, ecology and phenology, whereas the few specimens available for $S$. lycopersicoides and $S$. sitiens limited the predictiveness of the findings. This situation underscores the need for more collecting of the latter two species and better recording of passport data associated with specimens. As exemplified by the present study, collectors are justified in spending more time recording valuable passport data, which will serve as the basis for future taxonomic treatments as well as ecogeographic surveys.

\section{ACKNOWLEDGEMENTS}

The authors express their gratitude to Dr. Sandra Knapp for suggesting an ecogeography survey of these taxa and for identification of the specimens, and to Dr. David Spooner and an anonymous reviewer for useful comments. SDS would particularly like to thank Dr. Roger A. Smith for patiently reading and providing editorial suggestions on earlier versions of the manuscript. Finally, SDS acknowledges the Marshall Commemoration Commission for their generous financial support of her two years of study in the United Kingdom.

\section{LITERATURE CITED}

Child, A. 1990. A synopsis of Solanum subgenus Potatoe (G. Don) D'Arcy [Tuberarium (Dun.) Bitter (s.1.)]. Feddes Repert. Spec. Nov. Regni Veg. 101: 209-235.

Correll, D. S. 1962. The potato and its wild relatives. Contr. Texas Res. Found., Bot. Stud. 4: 1-606.

Grant, V. 1950. The flower constancy of bees. Bot. Rev. 16: 379-398.

Grosvenor, M. B. (ed.). 1966. Atlas of the World. National Geographic Society, Washington D.C.

Guarino, L., Maxted, N. \& Sawkins, M. 1999. Analysis of georeferenced data and the conservation and use of plant genetic resources. Pp. 1-24 in: Greene, S. L. \& Guarino, L. (eds.), Linking Genetic Resources and Geography: Emerging Strategies for Conserving and Using Crop Biodiversity. CSSA Special Publication, Madison, Wisconsin.

Hawkes, J. G. 1990. The Potato: Evolution, Biodiversity and Genetic Resources. Belhaven, London.

Hawkes, J. G. 1997. A database for wild and cultivated potatoes. Euphytica 93: 155-161.

Hollis, S. \& Brummitt, R. K. 1992. World Geographical Scheme for Recording Plant Distributions. Plant Taxonomic Database Standards No. 2. Hunt Institute, Pittsburgh.

Holmgren, P. K., Holmgren, N. H. \& Barnett, L. C. (eds.). 
1990. Index Herbariorum. Part I: The Herbaria of the World, ed. 8. New York Botanical Garden, New York.

Levin, D. A. 1978. The origin of isolating mechanisms in flowering plants. Evol. Biol. 11: 185-317.

Maxted, N., van Slageren, M. W. \& Rihan, J. 1995. Ecogeographic surveys. Pp. 255-286 in: Guarino, L., Ramanatha Rao, V. \& Reid, R. (eds.), Collecting Plant Genetic Diversity: Technical Guidelines. CAB International, Wallingford, Oxon.

Michener, C. D. 1962. An interesting method of pollen collecting by bees from flowers with tubular anthers. Revista Biol. Trop. 10: 167-175.

Peralta, I. E. \& Spooner, D. M. 2000. Classification of wild tomatoes: a review. Kurtziana 28: 45-54.

Peralta, I. E. \& Spooner, D. M. 2001. Granule-bound starch synthase (GBSSI) gene phylogeny of wild tomatoes (Solanum L. section Lycopersicon (Mill.) Wettst. subsection Lycopersicon). Amer. J. Bot. 88: 1888-2001.

Rick, C. M. 1951. Hybrids between Lycopersicon esculentum Mill. and Solanum lycopersicoides Dun. Genetics 37: 741-744.

Rick, C. M. 1979. Biosystematic studies in Lycopersicon and closely related species of Solanum. Pp. 667-678 in: Hawkes, J. G., Lester, R. N. \& Skelding, A. D. (eds.), The Biology and Taxonomy of the Solanaceae. Academic Press, London.

Rick, C. M. 1988. Tomato-like nightshades: affinities, autoecology and breeder's opportunities. Econ. Bot. 42: $145-154$.

Shaw, J. M. H. 1998. New combinations in Lycopersicon. New Plantsman 5: 108-109.

Spooner, D. M., Anderson, G. J. \& Jansen, R. K. 1993. Chloroplast DNA evidence for the interrelationships of tomatoes, potatoes and pepinos (Solanaceae). Amer. J. Bot. 80: 676-688. 